Economics and Sociology

Occasional Paper No. 2169

\title{
DO FINANCIAL INSTITUTIONS HAVE A ROLE IN ASSISTING THE POOR?
}

\author{
by \\ Claudio Gonzalez-Vega
}

September, 1994

Rural Finance Program

Department of Agricultural Economics

The Ohio State University

2120 Fyffe Road

Columbus, Ohio 43210-1099 


\begin{abstract}
This paper discusses the role of financial services in the reduction of poverty. It first examines changing views about poverty and the design of poverty alleviation programs, both in the United States and the developing countries. It claims that financial services can play a role in incorporating the poor in processes of economic growth, but not in mitigating the plight of those with no productive opportunities. The paper briefly reviews the functions of finance in the economy and argues that there is a public interest in promoting the efficient provision of financial services. One potential cost of poorly designed programs is thus a reduced efficiency of the financial system. Moreover, credit programs that in the past pursued non-financial objectives have been generalized failures. Thus, financial services can assist the poor only when they do what finance is supposed to do: facilitate payments and liquidity management, intermediate, and deal with risk. Moreover, deposit facilities are usually more important for the poor than loans. In turn, the demand for credit is not just a demand for loanable funds; it is a demand for a client relationship that offers a credit reserve. Since this requires a sense of permanency, institutional viability is required. Lack of viability was the greatest shortcoming of the subsidized, targeted credit programs of the past. Informal finance is reliable, but limited in scope. Viable formal intermediaries must be developed, but this is a costly exercise. A hospitable policy environment, appropriate technologies, and incentive compatible organizational designs are required.
\end{abstract}




\title{
DO FINANCIAL INSTITUTIONS HAVE A ROLE IN ASSISTING THE POOR? ${ }^{1}$
}

\author{
by \\ Claudio Gonzalez-Vega ${ }^{2}$
}

\section{Concerns about Poverty}

As we get ready to complete the first half of the decade of the 1990s, growing concerns about poverty stand out in political agendas all over the industrialized and the developing worlds. The stubbornness of poverty, even in the richest of nations, is being met with increasing impatience, and governments of diverse ideological persuasions are trying to do something about it, while donors and other international agencies have been rushed into offering their support to these efforts. But, from good intentions to actual successful remedies there is a long way. Thus, both conceptualizers and practitioners are once again looking for operational approaches to deal with poverty. And so, the old question re-emerges: What about credit?

As we well know, the extent to which the reduction of poverty and/or the alleviation of its consequences has been a public policy issue has differed significantly across countries and over time. Here in the United States, for example, poverty was at the top of the nation's agenda when

1 Keynote speech at the Conference "Financial Services and the Poor: U.S. and Developing Country Experiences," organized by the USAID Financial Sector Development Project (FSDP II) and The Brookings Institution, in Washington, D.C., on September 28-30, 1994. The style of the oral presentation is preserved.

2 Professor of Agricultural Economics and of Economics at The Ohio State University. Research in this area has been funded by the USAID Financial Resources Management (FIRM) Cooperative Agreement. The author is grateful to J.D. Von Pischke for the invitation and to several conference participants for comments. Additional comments have been received through the Devfinance electronic network based at Ohio State. 
the War on Poverty was declared exactly 30 years ago (Harrington). No more than two decades later, however, in the early 1980s, not only was poverty merely one of several explicit policy concerns, but many chose instead to highlight the counterproductive nature and high fiscal costs of some of the poverty alleviation programs that had been adopted earlier (Reagan). More recently, as we move into the 1990 s, public attention has focused again on the potential role of both government and of the publicly-supported non-government organizations (NGOs) in directly alleviating the continuing plight of the poor.

Three decades ago, as new programs were being introduced and old programs were being expanded, an optimistic view prevailed. The belief was that if stable economic growth could be maintained, government actions could actually solve the poverty problem if only sufficient resources were devoted to the task (Danziger and Weinberg). In the letter of transmittal of the 1964 Economic Report of the President, President Johnson announced: "We know what must be done, and this Nation of Abundance can surely afford to do it" (Johnson). Soon optimism was followed, however, by a diminishing faith in the government's ability to solve any problem (Aaron) and by strong arguments that social problems cannot be solved by "throwing money at them." Despite this skepticism, in the 1990s the pendulum of public opinion has been swinging back and new initiatives to address the challenge of poverty are being proposed.

In general, among these recent initiatives, specialized credit programs for the poor are becoming increasingly popular (Jordan; Minsky et al.). As many believe that a more effective design of the poverty alleviation programs would prevent their earlier shortcomings, it becomes critical to identify lessons learned from earlier experiments. What do we know about more effective program designs? As experience accumulates on the performance of credit (and of other) 
programs explicitly designed to assist the poor, there is thus a growing opportunity to take stock of which antipoverty policies have worked and which have not. A substantial abode of experience (positive and negative) on credit programs for the poor has been accumulated in low-income countries. Many of the lessons learned are relevant for the United States.

The evolution of public policy has not been different in the developing nations, where poverty is so conspicuous. Leaving behind the "basic needs" paradigm of the 1970s, for most of the developing world the 1980s were a "decade of structural adjustment," dominated by stabilization efforts designed to bring national expenditure in line with national income (or output) as well as by attempts to increase national income, through policy reforms that have promoted a more efficient use of resources (Grootaert and Kanbur).

There is a strong professional consensus that these adjustment programs of the 1980s were successful in moving many countries toward internal and external macroeconomic balance. The debate is intense, however, about whether these objectives could have been achieved "while better protecting the poor and providing the basis to incorporate them in the growth process."

This is not the place to solve this issue. To begin with, establishing causality between specific policies and the evolution of the standards of living of different socio-economic groups is a particularly difficult exercise. This is also the case, of course, of attempts to establish the impact of credit programs on final beneficiaries (Rhyne). In the case of structural adjustment efforts, in any case, the outcome depends strongly on the initial conditions and on the types of policies adopted. ${ }^{3}$

${ }^{3}$ I come from a country, Costa Rica, where these objectives of renewed growth with improved social conditions are being achieved quite successfully, and thus I am an optimist about well- 
In any case, regardless of whether the observed poverty outcomes of the 1980 s stemmed from past policies which militated against growth or from the adjustment policies that inevitably followed as the earlier strategies failed (Morley), there is no doubt that both low-income country governments and international donors have been increasingly concerned with poverty alleviation.

There are two dimensions to this preoccupation. A first type of concern relates to the need to achieve growth with equity over the long term. This requires policies and programs that foster the participation of the poor in the process of economic growth, by creating employment opportunities and by increasing their access to income-generating assets; and by raising the productivity of their assets, both physical and human (Grootaert and Kanbur). I believe that, if efficiently provided, financial services may play an important role in this task of incorporating (some of) the poor to processes of economic growth.

A second type of concern relates to the need to mitigate the transitional cost of adjustment for the most vulnerable groups of society. I believe formal financial services can play a very limited role in this effort, if any. Other fiscal mechanisms provide a more cost-effective approach to assist those unfortunate who have no productive opportunities and, therefore, no debt capacity. The use of credit in this case carries an excessive social cost and is easily counterproductive, as one would not want to burden the inviable with additional debt they cannot repay (Adams).

In dealing with these (poverty) issues it is always difficult to bridge the gap between moral obligations, calling for private and public charity, on the one hand, and the economic requirements that could improve the lot of the poor, on the other (Schultz). It appears, nevertheless, that

designed structural adjustment programs. 
financial services can have a sustainable economic role only in the second case, namely, when the opportunities for improvement do exist. To understand why this is the case, one needs to appreciate the nature of finance and the importance of its economic contributions.

\section{Functions of Finance}

The financial system is a key component of the institutional infrastructure that is required for the efficient operation of all markets. The most important contribution of the financial system is its ability to induce a larger size and foster a greater degree of integration of the markets for good and services, factors of production, and other assets. This expansion of markets is a precondition for powerful processes of division of labor and specialization, greater competition, the use of modern technologies, and the exploitation of economies of scale and of economies of scope. As already noted by Adam Smith, these are the processes that increase the productivity of available resources and lead to economic growth.

The expansion and integration of markets is achieved through the provision of monetization services and the efficient management of the payments system, the development of services of intermediation between surplus and deficit economics agents, and the establishment of opportunities for the accumulation of stores of value, the management of liquidity, and the transformation, sharing, pooling, and diversification of risk (Long).

Particularly important are the services of financial intermediation, which transfer purchasing power from agents with resources in excess of those needed to take advantage of their own (internal) opportunities (surplus agents, such as savers), to those with better opportunities but not enough resources of their own (deficit agents, such as investors). By making this division of 
labor between savers and investors possible, financial intermediaries channel resources from producers, activities, and regions with a limited growth potential to those where a more rapid expansion of output is possible.

Since there always are more economic agents who claim that they have superior uses for resources than there is purchasing power available, financial markets must contribute to the selection of the best possible uses of resources. These markets can also offer monitoring services, ensuring that funds are profitably used, as promised, and they can contribute to the enforcement of contracts, making sure that those who have borrowed repay the loans (Stiglitz). After all, finance is about promises to pay in the future that are expected to be fulfilled. The conditions of such repayment influence, in turn, who bears what risks.

I cannot sufficiently emphasize the extent to which the efficient provision of financial services is extremely critical for the operation of the economy at large. Because financial markets essentially influence the allocation of resources, Stiglitz has compared them to the "brain" of the entire economic system, the central locus of decisionmaking: if they fail. . .the performance of the entire economic system may be impaired. Why this is the case is a complex question, but if it is indeed so, there is clearly a major social interest at stake here. Most governments have recognized this and many have gone to extremes in order to prevent a collapse of their financial systems. Frequently, however, while recognizing but (mis)understanding their powers, governments have intervened in financial markets, in the pursuit of a varied range of worthy nonfinancial objectives, but with negative consequences. 


\section{Finance and Poverty: Lessons from the Past}

A good number of the initiatives to directly assist the poor with financial services (may) fall under this category of unsuccessful interventions. In considering such interventions, moreover, a key question to address is their potential cost in terms of the reduced efficiency of the financial system at large. This is a cost that it might be worth enduring, if the expected benefits were sufficiently large. Unfortunately, this is typically not the case, given the very nature of financial markets.

This is one of the most important lessons learned from earlier attempts to use formal financial markets to ostensibly promote particular activities, to compensate producers for other repressive policies, to free them from the grip of moneylenders, or to redistribute income towards the poor (Gonzalez-Vega 1993). The subsidized interest rates and administrative loan allocations through targeted credit programs, used for these purposes, did not displace informal sources of financial services and hardly promoted anything. They only redistributed income, but in reverse, from poor to rich (Gonzalez-Vega 1984). So, despite the best of intentions, they frequently turned out to be harmful for the particular segments of the population (marginal clientele) they had been set out to help.

These outcomes are well known and have been extensively documented for dozens of countries (Adams et al.). Too much effort was spent in small farmer credit programs, for example, to obtain meager results. The primary objective of increasing the farmers' access to formal credit was poorly met and a reduction in the cost of borrowing was achieved only for a few larger borrowers. Despite artificially low interest rates, formal credit did not become cheap for small rural producers and most credit portfolios became concentrated in a few hands. More 
importantly, these government-sponsored credit programs distracted attention from technological innovation, infrastructure development, and human capital formation, which directly increase the productivity of resources. Finance, instead, can only contribute to this goal indirectly, by making it possible for some to take advantage of the opportunities created by those other growth-inducing processes. In the absence of such opportunities, however, there is only a limited role for finance to play. ${ }^{4}$

There is an increasing body of evidence confirming that economic growth and reductions in poverty go hand in hand. Clearly, a substantial improvement in living standards requires economic growth (Biggs et al.). Further, securing full participation of the poor in such process is a long-term effort and it involves improving their employability, expanding the educational opportunities for their children, improving the performance of labor markets, creating a hospitable environment for their productive activities and much more. An efficient provision of the financial services that they demand is part (but only a part) of all of this process.

So, to the question "Can financial services be used to assist the poor in improving their lot?" the answer is "only when finance is allowed to do what finance is supposed to do." That is, only when:

(a) finance allows a transfer of purchasing power from uses with low to uses with high marginal rates of return;

(b) finance contributes to more efficient inter-temporal decisions about saving, the accumulation of assets, and investment;

4 Even in stagnant economies, nevertheless, finance plays a role in consumption smoothing. This role is frequently performed well by informal financial arrangements (Udry). 
(c) finance makes possible a less costly management of liquidity and accumulation of stores of value; and

(d) finance offers better ways to deal with the risks implicit in economic activities.

Otherwise, financial interventions (such as the early subsidized and targeted credit programs) are a weak instrument to achieve different, non-financial objectives and frequently lead to unexpectedly negative outcomes (Gonzalez-Vega, 1994). This section can be summarized with the proposition that many ingredients are needed for the poor to come out of poverty and that credit is only one of them. Credit is an important ingredient, but it is not even the most important one. Financial services play the key role of facilitating the work of growth-promoting forces, but only when the opportunities exist.

\section{Lessons Learned about Loans and Deposits}

A second important lesson learned from accumulated experience is that, among financial services, credit is not the only one that is important for the poor. In particular, deposit facilities provide valuable services for liquidity management and for the accumulation of stores of value by poor firm-households. Researchers are always surprised by the intensity of the demand for deposit facilities in the rural areas of very poor countries (Gonzalez-Vega et al.). Satisfaction of this demand has been a distinctive feature of programs that have been successful in delivering financial services to the poor (Robinson). An outstanding example is the unit desa program of the Bank Rakyat Indonesia, with over $12,000,000$ small depositors for only over $2,000,000$ small borrowers (Patten and Rosengard). Thus, while not all producers demand loans and, among those who do, 
they do not demand credit all of the time, most (if not all) economic agents demand deposit and other facilities for liquidity management and reserve accumulation, all of the time. ${ }^{5}$

A third lesson from direct experience is that the demand for credit is not just a demand for loanable funds. Finance is intimately linked to inter-temporal decisions, and in this sense it plays a critical role not only in savings and investment processes but also in dealing with the lack of synchronization between income generating (production) and spending activities (consumption and input use decisions), as well. Finance is also closely associated with risk management. It facilitates the accumulation of reserves for precautionary reasons (to be able to survive emergencies) and for speculative purposes (to be able to take advantage of unexpected future opportunities). For this, being creditworthy is critical.

Being creditworthy is equivalent to possessing a credit reserve: poor people do not necessarily want a loan now; they want the opportunity to get one, if and when they need it (Baker). They want this potential access to a loan to be reliable, to result in a timely and flexible disbursement of funds, to be always there. Because the informal sources of credit do offer these opportunities, poor people are reluctant to substitute formal sources of funds, no matter how subsidized, for the flexible and reliable informal financial arrangements that have served them well over the years.

Thus, what matters is not just access to loanable funds but the development of an established credit relationship. This, in turn, implies a sense of permanency of the financial

5 At the Conference, Catherine Mansell emphasized the importance of payments services, particularly for remittances and other money transfers. I fully agree that this is another important service for the poor. 
institution. A fourth lesson learned, in this connection, is that a financial intermediary cannot project an image of permanency if it does not provide valuable services (of high quality) to its clientele and if it is not financially and institutionally viable.

\section{Institutional Viability and the Poor}

With every program we have learned that the most severe deficiency of the earlier interventions to provide financial services to the poor was the lack of institutional viability of the organizations that were created for that purpose. Why does viability matter so much? Concern with viability springs first from a clear recognition of the scarcity of resources. If resources are limited, without self-sufficient financial institutions there is little hope for reaching the numbers of poor firm-households that are potential borrowers and depositors. The amounts required are beyond the ability and willingness of governments and donors to provide them (Otero and Rhyne). The alternative to viable organizations are expensive, inviable quasi-fiscal programs that reach only a select few beneficiaries. Thus, viability matters the most from this equity perspective: to be able to reach more than just a privileged few. Moreover, if the objective were just a one-time (transitory) injection of funds, then lump-sum transfers are always a more efficient way of accomplishing this. If, on the other hand, sustainability is important, then the viability of the financial organization matters.

Further, in addition to being fiscally feasible, the most important contribution of a concern with institutional viability is that it elicits appropriate incentives among all the participants in 
financial transactions. ${ }^{6}$ Thus, for example, while poor loan recovery rapidly destroys viability, an image of viability improves repayment discipline. A reputation as a good borrower in an established intermediary-client relationship is a more valuable intangible asset if the financial institution is expected to be permanent rather than transitory. When this intangible asset is sufficiently valuable, it elicits punctual repayment. When the organization's survival is questioned, on the other hand, default follows in stampede, and institutional breakdown becomes a self-fulfilling prophecy. Viability matters when repayment matters.

In this way, a concern with viability makes it possible to identify one way how interest rates and default rates are linked. Too low interest rates that cause intermediary losses are perceived by borrowers as signals of lack of permanency and thus delinquency follows. Moreover, in the same way that very high interest rates may induce adverse selection (Stiglitz and Weiss), too low rates tend to attract rent seekers who eventually default (Gonzalez-Vega 1993). Thus, both too high or too low interest rates may reduce expected intermediary profits through higher expected default rates.

As another example, the targeting of loan uses, irrelevant because of the fungibility of funds (Von Pischke and Adams), basically increases both lender and borrower transaction costs and reduces the quality of the services supplied by the intermediary and thus lowers the value of the intermediary-client relationship.

6 In this sense, financial viability concerns are a potential substitute for an appropriate structure of property rights, in generating compatible incentives among both the staff and the clients of the organization. 
In summary, targeting hurts viability in several ways. It reduces the scope for portfolio diversification in already highly specialized lenders. It limits the lender's degrees of freedom in screening loan applicants, and it reduces incentives for vigorous loan collection, shifting accountability for default from the lender to the donor that conditions the availability of funds to their use for specific targets (Aguilera-Alfred and Gonzalez-Vega). More interested in monitoring compliance with the targets, for a long time many donors ignored this potential impact of targeting on delinquency, but they were very surprised when rampant default destroyed the institutions that had been (ab)used to easily channel donor funds.

Finally, deposit mobilization is also intimately linked to the importance of institutional viability. Deposits provide information to the lender about the potential borrowers, create a basis of mutual trust, and facilitate the accumulation of a downpayment that can serve as a deductible in any future loan contract. Deposits contribute, therefore, to the solution of difficult information problems frequently encountered in financial markets. Moreover, healthy deposit mobilization creates an image of institutional viability that promotes repayment. Thus, while donor-funded loans may not be repaid, those funded with the neighbor's deposits are (Aguilera-Alfred and Gonzalez-Vega).

Most importantly, depositors create institutional independence from the whims of donors and politicians; they shield the financial organization from political intrusion (Poyo, GonzalezVega and Aguilera-Alfred). In general, deposit mobilization contributes to sustainability and to an organizational environment (corporate culture) where permanency becomes an important (compatible) incentive to attract and retain competent managers and induce the agency's staff to 
behave in ways compatible with the viability of organization. ${ }^{7}$ For them, the value of their relationship with the organization increases when deposits are an important source of funds. This encourages correct decisions and effort (Chaves 1993).

\section{Formal and Informal Finance}

Recapitulating my statements up to this point:

(a) The poor need more than just financial services; the non-financial ingredients of growth and development matter.

(b) The poor need more than just credit; deposit facilities may matter even more.

(c) The poor need more than just loanable funds; they need a permanent, flexible and reliable credit relationship.

(d) In consequence, the poor need viable, efficient, profitable, well-managed financial intermediaries with which to establish these permanent relationships.

One important additional lesson increasingly learned over the past decades is that informal financial arrangements are pervasive and very successful in providing several (some) types of financial services among the poor (Bouman and Hospes). They are timely, reliable, and levy low transaction costs on their clients, mostly for loans of small amounts and at short terms. The value and importance of these informal financial arrangements have been increasingly recognized and visions of exploitation have been replaced by attempts to either replicate their features or link

7 Deposit mobilization, on the other hand, is not an easy task. It requires an appropriate organizational design, liability management techniques, and prudential supervision to protect depositors. 
informal lenders to national financial networks (Adams and Fitchett). But, as Hugo Pirela has asked "if this is the case, why would additional (semi-formal and formal) financial intermediaries be needed to do a job that indigenous, informal arrangements are already doing to well?" The fact is that, despite their valuable contributions, informal financial arrangements suffer from several limitations.

These shortcomings stem from the very features that make informal transactions competitive in the first place. They are grounded in the local economy and are thereby limited by the local wealth constraints and the covariant risks of the local economy. As a result, their frontier is narrow; they do not go far enough in scope (geographically, over time, and across products). Informal finance provides valuable services, but in small amounts, for short periods of time. These services are not always good vehicles for long-term investment, for example. More importantly, because they are cost effective only in the immediate neighborhood, informal transactions do not overcome market segmentation and do not contribute much to the most important function of finance: the integration of markets. For this task, formal financial institutions with a national scope are required.

\section{The Costs of Finance}

Developing national financial systems is not an easy task. The main reason is that the provision of financial services is very expensive. Formal financial services are almost equivalent to a luxury good. Their production requires valuable human and material resources with high opportunity costs. Moreover, mistakes in the evaluation of creditworthiness are costly both for the intermediary and for society. 
Some of these costs are associated with getting the transacting parties together. In this task, formal finance usually implies high fixed costs; this is certainly the case with bank branches. These fixed costs loom particularly high when the clients are small, heterogeneous, and dispersed in sparsely populated areas. The key to the level of these costs is market size, and this is not unique to financial services. It is expensive to provide health, education, or entertainment in remote areas with a low density of population. In informal finance, on the other hand, these costs are low, given the nature of the technologies used and the proximity of the transacting parties.

Moreover, successful finance requires inputs for screening loan applicants (information management for creditworthiness evaluation and loan approval), for monitoring borrowers, and for the efficient design and enforcement of contracts. These costs are a function of distance (geographic, occupational, ethnic) and of feasible technologies used to produce these services. In addition, alternative technological arrangements result in specific comparative advantages in the provision of financial services in specific market niches. The choice of appropriate technology thus becomes critical.

Much technological progress has taken place in the area of microfinance (Christen, Rhyne, and Vogel). The key to success is to design an intervention that is properly dimensioned to the size of the market and compatible with the nature of the clientele (Chaves and Gonzalez-Vega). Traditional banking technology, for example, is prohibitively expensive for loans to the poor. Both lender and borrower transaction costs are too high in this case. Moreover, as the poor are so heterogeneous, so are the financial services that they demand, creating opportunities for different types of intermediaries. 
Banks may, of course, adopt more information-intensive technologies than those that rely on traditional collateral; that is, embark on "downgrading" strategies (Krahnen and Schmidt). Although there are major advantages in using banks as intermediaries, to reach marginal clientele they need a technological revolution. Other non-bank organizations may possess comparative advantages in information and contract enforcement among this clientele. They may eventually be "upgraded" to become more like banks.

In either case, the challenge is to bring together those who have the informational and enforcement advantages (usually local agents) and those with sufficient resources and a willingness to lend and to accept the risks implied (governments and donors). This generates, however, significant agency costs as governments, donors, apex organizations, or bank headquarters have to monitor the decentralized operations of branches, credit unions, NGOs and the like (Jensen and Meckling).

\section{The Role of Organizations}

There are two possible approaches to the question of improving access to credit by particular groups, such as the poor:

(a) One may mandate portfolio quotas at banks and create special targeted lines of credit within existing formal institutions. Most likely this will not be the appropriate technology to reach the poor. One may even mandate subsidized loans for the target group; this has always been counterproductive, hurting in the end the intended beneficiaries.

(b) Alternatively, one may promote the development of viable intermediaries with a vocation for and a comparative advantage in specific market niches. The desired clientele would 
be reached indirectly, by targeting the development of institutions that typically service these groups. In this way, the problem will be addressed by developing appropriate technologies.

For this second approach to be successful, however, some strict conditions must be met. Past experience has shown that no constraints on risk management should be placed on the lender, which should have full flexibility in evaluating creditworthiness and in collecting loans. In general, these intermediaries should be allowed to operate on market terms. These are common features of successful interventions, which have worked with, not against, the market (Chaves and Gonzalez-Vega).

Appropriate technology is clearly a necessary condition for reaching the poor with sustainable financial services. It is not a sufficient condition, however. While policies, procedures and technologies matter, policies will not be enacted, procedures will not be revised, and technologies will not be adopted, unless it is in someone's interest to do so. In the end, all decisions are made by individuals, who pursue their own objective functions, given existing constraints.

Institutions constrain individual behavior, define property rights and incentives, and embody the rules of the game (North). Organizational design matters a lot because individual choices are induced and/or constrained by the structure of incentives within the organization. Organizational design is critical because it influences behavior and behavior influences performance. If what matters is not just loanable funds but viable organizations, emphasis on designing efficient and viable organizations is critical. The dilemma is that a flood of donor and government funds tends to destroy adequate organizational designs. Because wealth constraints 
matter, how to overcome those constraints without at the same time destroying the intermediary involved is a major challenge.

It seems that the most difficult remaining question in the provision of financial services to the poor is thus the design of organizations with the correct structure of incentives and governance rules (Chaves 1994). As this depends so much on the structure of property rights of the organization, there are serious questions about the extent to which intermediaries with diffused property rights structures (such as the old public development banks and the new NGOs) or with conflicting governance rules (such as credit cooperatives) will be able to generate sustainable financial intermediation. The greatest challenge for the progress of finance for the poor, therefore, is in the institutional design of such organizations. This is, according to Krahnen and Schmidt, the most promising and critical area for future donor assistance.

Moreover, because of several limitations of locally-based financial arrangements (limited opportunities for risk diversification and intermediation), appropriate links of the local intermediaries to the aggregate financial system must be established, in order to increase the viability of enforcement-effective and informationally-advantaged agents, which may suffer from local, covariant, systemic risks and from limited opportunities for intermediation between surplus and deficit units. Ultimately, what matters is the development of financial systems and networks (e.g., new ways of economic organization). As markets grow and institutions are developed, formality will increase (although informality will not disappear), and the introduction of modern institutions will be required. For this, appropriate policies, cost-effective technologies, and viable organizational designs will still be needed. 


\section{REFERENCES}

Aaron, Henry (1978), Politics and the Professors: The Great Society in Perspective, Washington, D.C.: Brookings Institution.

Adams, Dale W (1994), “Altruistic or Production Finance?: A Donor's Dilemma," Economics and Sociology Occasional Paper No. 2150, Columbus, Ohio: The Ohio State University.

Adams, Dale W and Delbert A. Fitchett (eds.), (1992), Informal Finance in Low-Income Countries, Boulder, Co.: Westview Press.

Adams, Dale W, Douglas H. Graham, and J.D. Von Pischke (eds.), (1984), Undermining Rural Development with Cheap Credit, Boulder, Co.: Westview Press.

Aguilera-Alfred, Nelson and Claudio Gonzalez-Vega (1993), "A Multinomial Logit Analysis of Loan Targeting and Repayment at the Agricultural Development Bank of the Dominican Republic," Agricultural Finance Review, Vol. 53: 55-64.

Baker, Chester (1973), "Role of Credit in the Economic Development of Small Farm Agriculture," Small Farmer Credit Analytical Papers, Washington, D.C.: Agency for International Development Spring Review of Small Farmer Credit.

Biggs, Tyler, Merilee S. Grindle and Donald R. Snodgrass (1988), "The Informal Sector, Policy Reform, and Structural Transformation," in Jerry Jenkins (ed.), Beyond the Informal Sector. Including the Excluded in Developing Countries, San Francisco, Ca.: Institute for Contemporary Studies.

Bouman, F.J.A. and Otto Hospes (eds.) (1994), Financial Landscapes Reconstructed. The Fine Art of Mapping Development, Boulder, Co.: Westview Press.

Chaves, Rodrigo A. (1993), "Permanencia y Viabilidad de las Organizaciones Privadas de Desarrollo y sus Fuentes de Recursos," in Claudio Gonzalez-Vega and Tomas MillerSanabria (eds.), Financiamiento y Apoyo a la Microempresa, San Jose: The Ohio State University and Academia de Centroamerica.

Chaves, Rodrigo A. (1994), "The Behavior and Performance of Credit Cooperatives: An Analysis of Cooperative Governance Rules," Ph.D. Dissertation, Columbus, Ohio: The Ohio State University.

Chaves, Rodrigo A. and Claudio Gonzalez-Vega (1994b), "The design of Successful Rural Financial Intermediaries: Evidence from Indonesia," World Development, forthcoming. 
Christen, Robert Peck, Elisabeth Rhyne and Robert C. Vogel (1994), "Maximizing the Outreach of Microenterprise Finance: The Emerging Lessons of Successful Programs," Washington, D.C.: IMCC, unpublished report.

Danziger, Sheldon H. and Daniel H. Weinberg (1986), "Introduction," in Sheldon H. Danziger and Daniel H. Weinberg (eds.), Fighting Poverty. What Works and What Doesn't, Cambridge, Mass.: Harvard University Press.

Gonzalez-Vega Claudio (1984), "Cheap Agricultural Credit: Redistribution in Reverse," in Dale W Adams, Douglas H. Graham, and J.D. Von Pischke (eds.), Undermining Rural Development with Cheap Credit, Boulder, Co.: Westview Press.

Gonzalez-Vega, Claudio (1993), "From Policies, to Technologies, to Organizations: The Evolution of The Ohio State University Vision of Rural Financial Markets," Economics and Sociology Occasional Paper No. 2062, Columbus, Ohio: The Ohio State University.

Gonzalez-Vega, Claudio (1994), "Stages in the Evolution of Thought on Rural Finance. A Vision from The Ohio State University," Economics and Sociology Occasional Paper No. 2134, Columbus, Ohio: The Ohio State University.

Gonzalez-Vega, Claudio, Jose Alfredo Guerrero, Archibaldo Vasquez and Cameron Thraen (1992), "La Demanda por Servicios de Depósito en las Areas Rurales de la República Dominicana," in Claudio Gonzalez-Vega (ed.), República Dominicana: Mercados Financieros Rurales y Mouilización de Depósitos, Santo Domingo: The Ohio State University.

Grootaert, Christiaan and Ravi Kanbur (1990), "Policy-Oriented Analysis of Poverty and the Social Dimensions of Structural Adjustment," Washington, D.C.: The World Bank SDA Working Paper.

Harrington, Michael (1962), The Other America: Poverty in the United States, New York: MacMillan.

Jensen, Michael C. and William H. Meckling (1976), "Theory of the Firm, Managerial Behavior, Agency Costs, and Ownership Structure," Journal of Financial Economics, 3:305-360.

Johnson, Lyndon (1964), "Letter of Transmittal," in Economic Report of the President, Washington, D.C.: GPO.

Jordan, Jerry L. (1993), “Community Lending and Economic Development," Economic Commentary, Federal Reserve Bank of Cleveland, November.

Krahnen, Jan Pieter and Reinhard H. Schmidt (1994), Development Finance as Institution Building. A New Approach to Poverty-Oriented Banking, Boulder, Co.: Westview Press. 
Long, Millard (1983), "A Note on Financial Theory and Economic Development," in J.D. Von Pischke, Dale W Adams and Gordon Donald (eds.), Rural Financial Markets in Developing Countries. Their Use and Abuse, Baltimore: The Johns Hopkins University Press.

Minsky, Hyman P. et al. (1993), "Community Development Banking," Public Policy Brief No. 3, Annandale-on-Hudson, NY: The Jerome Levy Economics Institute of Bard College.

Morley, Samuel A. (1994), Poverty and Inequality in Latin America: Past Evidence, Future Prospects, Washington, D.C.: Overseas Development Council Policy Essay No. 13.

North, Douglass C. (1992), Transaction Costs, Institutions, and Economic Performance, San Francisco, CA: International Center for Economic Growth.

Patten Richard H. and Jay K. Rosengard (1991), Progress with Profits. The Development of Rural Banking in Indonesia, San Francisco, Ca.: International Center for Economic Growth.

Pirela Martinez, Hugo (1990), "The Grey Area in Microenterprise Development," Grass Roots Development, Vol. 14, No. 2: 33-40.

Poyo, Jeffrey, Claudio Gonzalez-Vega and Nelson Aguilera-Alfred, "The Depositor as a Principal in Public Development Banks and Credit Unions: Illustrations from the Dominican Republic," Economics and Sociology Occasional Paper No. 2061, Columbus, Ohio: The Ohio State University.

Reagan, Ronald (1982), "Remarks Before the National Black Republican Council," September 14, 1982 Weekly Compilation of Presidential Documents, 18: 1152-1157, Washington, D.C.: GPO.

Rhyne, Elisabeth (1994), "A New View of Finance Program Evaluation," in Maria Otero and Elisabeth Rhyne (eds.), The New World of Microenterprise Finance. Building Healthy Financial Institutions for the Poor, West Hartford, Conn.: Kumarian Press.

Rhyne, Elisabeth and Maria Otero (1994), "Financial Services for Microenterprises: Principles and Institutions," in Maria Otero and Elisabeth Rhyne (eds.), The New World of Microenterprise Finance. Building Healthy Financial Institutions for the Poor, West Hartford, Conn.: Kumarian Press.

Rhyne, Elisabeth and Linda S. Rotblatt (1994), What Makes Them Tick? Exploring the Anatomy of Major Microenterprise Finance Organizations, Cambridge, Mass.: ACCION International monograph Series No. 9. 
Robinson, Marguerite S. (1994), "Financial Intermediation at the Local Level: Lessons from Indonesia," Cambridge, Mass.: Harvard Institute for International Development, Development Discussion Paper No. 482.

Robinson, Marguerite S. (1994), "Savings Mobilization and Microenterprise Finance: The Indonesian Experience," in Maria Otero and Elisabeth Rhyne (eds.), The New World of Microenterprise Finance. Building Healthy Financial Institutions for the Poor, West Hartford, Conn.: Kumarian Press.

Shultz, Theodore W. (1992), "Foreword," in Tarsicio Costañeda, Combatting Poverty. Innovative Social Reforms in Chile During the 1980s, San Francisco, Ca.: International Center for Economic Growth.

Stiglitz, Joseph E. (1993), "The Role of the State in Financial Markets," Proceeding of the World Bank Annual Conference on Development Economics.

Stiglitz, Joseph E. and Andrew Weiss (1981), "Credit Rationing in Markets with Imperfect Information," American Economic Review, Vol. 71, No. 3: 393-410.

Udry, Christopher (1990), "Credit Markets in Northern Nigeria: Credit as Insurance in a Rural Economy," The World Bank Economic Review, Vol. 4, No. 3, pp. 251-71.

Von Pischke, J.D. (1991), Finance at the Frontier. Debt Capacity and the Role of Credit in the Private Economy, Washington, D.C.: The World Bank.

Von Pischke, J.D. and Dale W Adams (1983), "Fungibility and the Design and Evaluation of Agricultural Credit Project," American Journal of Agricultural Economics, Vol. 62, No. 4, November. 
